\title{
Comparing climate change perceptions and meteorological data in rural West Africa to improve the understanding of household decisions to migrate
}

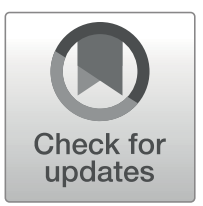

\author{
Florence De Longueville ${ }^{1} \cdot$ Pierre Ozer $^{2}$ • François Gemenne ${ }^{2} \cdot$ Sabine Henry ${ }^{1}$ • \\ Ole Mertz ${ }^{3}$. Jonas $\emptyset$. Nielsen ${ }^{4}$
}

Received: 26 July 2019 / Accepted: 19 March 2020 / Published online: 17 April 2020

(C) Springer Nature B.V. 2020

\begin{abstract}
Largely dependent on rain-fed agriculture, the West African populations could be severely impacted by climate change and variability. In this paper, we performed a literature review relating to perceptions of climate change and variability in West Africa, followed by an indepth comparison between perceptions by rural dwellers of Burkina Faso and trends in meteorological data to discuss the importance of perceptions vis-à-vis climate trends in migration decision. Results showed that respondents perceived increasing temperature and worsening rainfall conditions over 1988-2007 matching with findings of previous studies but inconsistent with the trends observed in rainfall data. Given that climate change is recognized as a key driver of mobility on the one hand and the fact that climate change perceptions influence decision to migrate on the other hand, our results suggest to jointly include perceptions and climate data in future research on environmental migration in order to improve the understanding of household's decision in response to climate change.
\end{abstract}

Keywords Adaptation $\cdot$ Burkina Faso $\cdot$ Climate change $\cdot$ Migration $\cdot$ Perception

Electronic supplementary material The online version of this article (https://doi.org/10.1007/s10584-02002704-7) contains supplementary material, which is available to authorized users.

Florence De Longueville

florence.delongueville@unamur.be

1 Department of Geography \& Intitute of Life-Earth-Environment, University of Namur, Namur, Belgium

2 The Hugo Observatory, Department of Geography, University of Liège, Liège, Belgium

3 Department of Geosciences and Natural Resource Management, University of Copenhagen, Copenhagen, Denmark

4 Geography Department, Humboldt University zu Berlin, Berlin, Germany 


\section{Introduction}

Climate change and variability adversely impact the livelihood of populations dependent on rain-fed agriculture (Juana et al. 2013). Rainfall variability and drought, through their negative impacts on crop production and livestock, are significant contributors to poverty and food insecurity (de Sherbinin 2011). Particular attention must be paid to West Africa for three reasons: this region will be among those most highly affected by climate change in the future, there is a prevalence of agriculture in its economy and the majority of its rural population closely depends on the natural environment (Van der Land et al. 2018).

To face climate variability and economic or political changes, the rural populations of West Africa develop adaptation strategies that will vary according to region, type of farming and sociocultural factors (Adger et al. 2009; Nielsen and Reenberg 2010a). Soil fertility management practices and irrigation contribute to counteract the negative impacts of climate change but some farmers do not adopt these measures due to their unavailability and high cost. Soil and water conservation practices are frequently implemented in the West African Sahel but mainly because of growing land scarcity and new market opportunities rather than climate variability (Barbier et al. 2009). In most places, the only technical adaptations in response to climate change are to use several crop varieties or mix-cropping and/or to postpone seeding dates (Fosu-Mensah et al. 2012). In several regions, farmers choose to integrate crop and livestock and to plant trees (Soglo and Nonvide 2019). Cyclical intraregional migration in response to seasonal variability in rainfall and periodic droughts has long been practiced in West Africa (Cordell et al. 1996). Today, as migration is recognized as an adaptation strategy (Cissé et al. 2010; Mertz et al. 2010), farmers are diversifying their livelihood to avoid relying on a single rainfall-dependent activity and to increase household income, notably used to buy food (D'haen et al. 2011; Nielsen and Reenberg 2010b). In some cases, migrations are rather a failure to adapt, when households fall in the vicious circle of livelihood deterioration by moving to areas where they are exposed to more risks (Afifi et al. 2016).

Over the last three decades, the role of climate change in driving human migration has attracted a growing interest (de Longueville et al. 2019; Kaczan and Orgill-Meyer 2019). Three literature reviews on the environment-migration nexus in West Africa (Brüning and Piguet 2018; Van der Land et al. 2018) and in Africa (Borderon et al. 2018) have recently been published. In the first review, the authors analysed 43 studies about environmental change and migration in West Africa and concluded that it is undeniable that the environment plays a role in decisions to migrate (along with other factors) (Brüning and Piguet 2018). They also highlighted three weaknesses that could guide future research on these issues: (i) strengthen analysis of community contexts, household strategies and individual choices, (ii) use mixed methods and (iii) focus on perceptions of climate change and variability. The second review analysed 15 empirical case studies that focus explicitly on the complex links between environmental factors and human mobility in West African drylands (Van der Land et al. 2018). The authors noted ambiguous findings on the impact of environmental factors on migration. Nevertheless, they observed that all studies reviewed agree on three relevant aspects: (i) environmental conditions and changes favour temporary migration, (ii) migration is a well-established activity to diversify income and (iii) migration is multi-causal. They also noted that studies which consider multiple variables as drivers of migration find that environmental factors are often not the main driver. The third review analysed 53 studies on the environment-migration nexus in Africa, including 25 in West Africa (Borderon et al. 2018). In this paper, the authors provided a first systematic and comprehensive summary of empirical evidence on environmental drivers of migration in Africa considering direct and indirect pathways through which environmental change influences internal and international migrations. Results showed that environmental change 
influences migration in Africa in an indirect way, i.e. through affecting other drivers of migration (sociodemographic, economic, political factors). This supports the conceptual framework proposed by Black et al. in 2011 for understanding and assessing the effects of environmental change on human migration (see Fig. 4, above).

Studies about the environment-migration nexus are largely based on conventional climate data based on recorded measures (Obokata et al. 2014). This was confirmed by two review articles having showed that environmental conditions are exclusively represented by ground-measured climate data, global climatological datasets and/or satellite data (Eklund et al. 2016; Neumann and Hilderink 2015). Historical climate change patterns usually rely on the characterization of long-term trends of key climate indicators and their variability in relation to a reference period (Razavi et al. 2016). While scientists are often sceptical regarding the reliability of climatic observations made by non-scientists, it has been demonstrated that farmers' perceptions of rainfall patterns and variability can add valuable information to conventional meteorological statistics and that only farmers who perceive a climate problem will adapt to it (Simelton et al. 2013). Findings of studies about perceptions of climate change and variability all over the world agree that populations perceive changes in local weather patterns, noticeable in rainfall (seasonality, distribution, amount and intensity) and in temperature. It is argued that climate change perceptions and their impacts on activities and livelihood influence people's decisions regarding whether to act or not (Alessa et al. 2008) and what adaptation measures are taken over both short and long terms (Byg and Salick 2009; Reckien 2014). It is also increasingly recognized that relying more on change perceptions than on observed change accounts for the fact that some people decide to leave their homes when experiencing environmental stressors, while others do not (Black et al. 2013; Hunter et al. 2015). Some authors claim that people's perception of climate change and their own vulnerability to climate variability are factors related to migration decisions (Hunter 2005; Izazola et al. 1998) while others deplore a lack of empirical studies about relation between climate change perceptions and migrations (Brüning and Piguet 2018; Hunter et al. 2015). Recently, researchers have conducted empirical studies in Vietnam, Cambodia, Uganda, Nicaragua and Peru including data on perceptions to provide a more complete representation of the migration decisions. It appears that the individual perceptions of slow-onset events (droughts) decrease the probability to migrate. On the contrary, the perceptions of sudden events (floods, hurricanes) are associated with a higher probability to migrate, but results are not significant (Koubi et al. 2016a). A comparative study of the perceptions between migrants and non-migrants in Vietnam showed that the non-migrants have a better perception of sudden events but underestimate slowonset events (Koubi et al. 2016b). In the context of the "Where the rain falls" project, questions covering human mobility attempted to identify links between this variable, food and livelihood security and rainfall variability (Afifi et al. 2016; Rademacher-Schulz et al. 2014; Warner and Afifi 2014). Led with the aim to compare opportunities for migration as a successful adaptation strategy in eight countries, these studies use perceptions of respondents instead of observed climate data but provide no check of the consistency between the two sets of data, except in the few cases where it was shown that the perceptions match with climate trends.

Studies on environmental migrations thus traditionally use conventional climate data. A few exceptions can be found in recent literature with the use of climate change perceptions instead of climate data (e.g. Afifi et al. 2016; Rademacher-Schulz et al. 2014) but no single study so far has yet systematically combined climate data and data on climate change perceptions. Doing so is, however, needed if we are to understand how perception of climate change and variability are different from or similar to scientifically observed trends, and how the use of both types of data in single studies can improve our understanding of migration decision in rural West Africa. To explore this, the paper starts with an in-depth review of scientific literature relating to climate change 
perceptions in this region and their matching with climate trend observations. Then, we propose a comparison between climate change perceptions by rural dwellers in Burkina Faso and climate trends based on an original set of indicators performed in optimal study conditions. The discussion draws out some larger implications of our results for the current debate on the adaptation strategies in response to climate change in West Africa, especially concerning decisions to migrate.

\section{Literature review}

A systematic literature review was undertaken to identify relevant studies investigating perceptions of climate change and variability in arid, semi-arid and sub-humid areas of West Africa, including Senegal, Gambia, Mauritania, Mali, Burkina Faso, Niger, Nigeria, Benin, Togo, Ghana and Ivory Coast. The Scopus and Google Scholar databases were queried using 'Perception' AND 'Climate change' or 'Climate variability' AND 'West Africa' or 'Senegal' (or any country quoted earlier). All papers returned by the search were evaluated and a total of 49 articles were identified as relevant. They have all been published between 2008 and 2019, confirming that perception of climate change is a relatively new field of research (Ozer and Perrin 2014). For each paper, we determined the study area, acquisition method of perception data, perceptions of climate change and variability, use of climate data, study period and findings from a comparison between perceptions and observations (see Supplementary material).

The content of the 49 papers returned by the search was analysed. Results highlighted that the most important changes felt by the West African populations are a decrease in total annual rainfall amount, a shorter rainy season and an increase in dry spells during the rainy season, in periodic droughts, in irregular rainfall and in temperature (see Supplementary material). In Burkina Faso, for example, respondents perceived that over the last 30 years, the climate had become warmer (73\%); the rainfall amount had decreased (97\%) with a change in intensity $(92 \%)$ and frequency (92\%). A delayed onset (63\%) and an early cessation (90\%) of the rainy season were also noted (Kima et al. 2015).

Without exception, studies agree that the West African populations perceive changes in weather conditions. However, there is disagreement about consistency with scientifically observed trends. Of the 49 articles returned by the search, 21 did not make any comparison (see Cat. 1 in Supplementary material). Of the remaining 28 articles that do introduce a comparison, 17 concluded that there was consistency between what populations perceived and what has been published in scientific reports or observed in weather data (see Cat. 2 in Supplementary material). On the other hand, 11 articles showed that the populations' perceptions are partially or totally inconsistent with scientific observations (see Cat. 3 and 4 in Supplementary material). This did not concern temperature but rainfall change. Discrepancies between perception and observation also exist in the findings of studies led in other African regions (e.g. Meze-Hausken 2004; Sutcliffe et al. 2016) and in other parts of the world (e.g. López et al. 2017; Niles and Mueller 2016). In literature, reasons explaining these discrepancies are classified into two groups. The first group is related to limitations of specific used data sources and methods: an irrelevant choice of the study period, a set of imprecise survey questions about climate change perception, the use of a single inappropriate meteorological dataset and/or irrelevant definitions of meteorological indicators can contribute to introduce biases in comparison. The second group includes inherent differences between perceptions and meteorological data, even when both have been measured with accuracy (Dickinson et al. 2017).

Faced with these contradictory results about consistency between perceptions of climate change and variability and scientifically observed trends in West Africa, we used the opportunity 


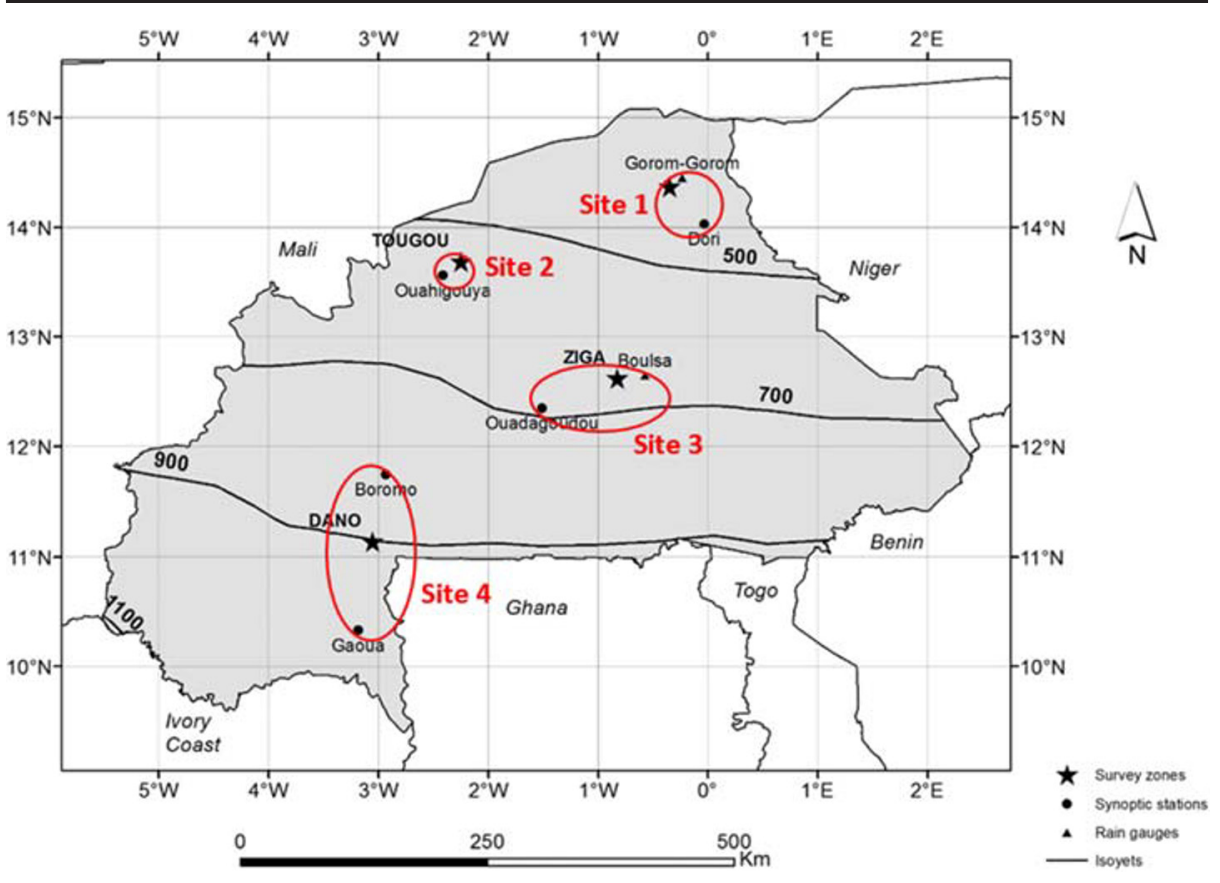

Fig. 1 Survey distribution and the location of meteorological stations in the study area with isohyets from 1971 to 2010

provided by access to relevant perception data and reliable daily meteorological data for Burkina Faso, in order to proceed to a new comparison based on an original set of indicators. We tried to optimize study conditions (databases, method) to minimize the risk of obtaining differences between perceptions and observations due to data constraints or methodological choices.

\section{Empirical study}

In this part, we have compared climate change perceptions of rural dwellers with meteorological records in Burkina Faso. This landlocked country occupying a central geographical position in West Africa encompasses a diverse range of climates (Fig. 1) and is characterized by a unimodal rainfall regime with a peak in August. Burkina Faso is a resource-poor country whose struggling economy is heavily dependent on rain-fed agriculture and has been identified as vulnerable to climate-induced displacements (Gray and Wise 2016; Henry et al. 2004).

\subsection{Data}

\subsubsection{Perception data}

Data on perceptions of climate change and variability were extracted from the household survey of the $\mathrm{AMMA}^{1}$ project carried out in five West African countries between November 2007 and June 2008. These perception data are particularly relevant for the following reasons:

\footnotetext{
${ }^{1}$ African Monsoon Multidisciplinary Analysis
} 
- They were collected on the basis of clear questions covering changes in temperature during dry and rainy seasons and different aspects of rainfall pattern and variability (amount, frequency, intensity, seasonal characteristics...) (Mertz et al. 2012) (see Table 1). Methods differ across studies but it was acknowledged that the use of specific questions has the benefit of eliciting perceptions on each parameter from every respondent, facilitating comparisons with meteorological data (Dickinson et al. 2017).

- The AMMA project made the choice of a time scale of 20 years (1988-2007) before the time of survey in 2008 to collect climate change perceptions. This is consistent with other studies (Bryan et al. 2009; Tambo and Abdoulaye 2012). A period of 20 years is relevant concerning "memory of surveyed people". Interviewers were asked to collect information on changes and trends during this period, rather than a comparison between 1988 and 2007.

- The survey sample size $(N=383)$ was suitable according to previous studies (e.g. Ayanlade et al. 2017; Kima et al. 2015).

- Respondents were members of rural households located in four sites of Burkina Faso (see Fig. 1). Thanks to the small spatial size of the surveyed site, we can reasonably argue that people are exposed to the same meteorological conditions within each site. By contrast, the four sites belong to different climate zones, which allows us to make comparisons related to the level of aridity.

In the AMMA database, there are also three categories of information about migration: (i) the number of temporary and permanent migrants in the households at the time of the survey with the main cause of migration, (ii) migration seen as a positive/negative consequence of observed changes, as well as a solution to solve other negative consequences and (iii) the intention to migrate in the future, temporarily or permanently, in the case of more frequent droughts and in the case of drier or wetter climates (Mertz et al. 2011), among other adaptation strategies. It is important to note that the intention to

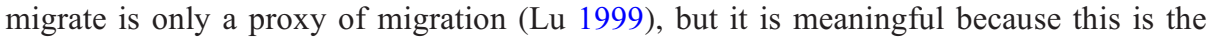
first step in the actual migration process (Macleod 1996). We used these data to complete our analysis.

\subsubsection{Meteorological data}

Meterological data were provided by the Direction Générale de la Météorologie du Burkina Faso. These data include daily rainfall and minimum and maximum temperatures from January 1988 to December 2007 at a national scale. We retained data from four synoptic stations $^{2}$ and two additional rain gauge stations selected on the basis of the proximity to the surveyed villages (Fig. 1). This allowed us to compare climate change perceptions with changes calculated from meteorological data measured at the nearest synoptic station(s) to each study site. This criterion of proximity was the same in Osbahr et al. (2011), Sutcliffe et al. (2016) and Ayanlade et al. (2017), who justified this choice to minimize impact of spatial variability. The availability of these data had two advantages:

- It made possible the calculations of an original set of indicators. This was interesting because perceptions of rainfall change can reflect a change in visible variables like frequency of extremes or seasonality rather than total rainfall (Roncoli et al. 2002).

\footnotetext{
$\overline{2}$ The station of Gaoua was only used for rainfall trends because anomalies were detected in temperature data
} 
Table 1 Definition and unit of rainfall and temperature indices reflecting questions of climate change perception in the AMMA survey (rs rainy season, $d s$ dry season)

\begin{tabular}{|c|c|c|c|c|}
\hline & \multirow{3}{*}{$\begin{array}{l}\text { Perception, from } \\
\text { AMMA survey } \\
\text { Parameter }\end{array}$} & \multicolumn{3}{|c|}{ Observation, from meteorological stations } \\
\hline & & \multicolumn{3}{|c|}{ Translation } \\
\hline & & Index & Definition & Unit \\
\hline \multirow[t]{20}{*}{ Rainfall } & \multirow{4}{*}{$\begin{array}{l}\text { Total rainfall during } \\
\text { the rainy season }\end{array}$} & TOTRrs & Total rainfall during rs & $\mathrm{mm}$ \\
\hline & & RDrs & Total days with rainfall during rs & days \\
\hline & & TOTR & Total annual rainfall & $\mathrm{mm}$ \\
\hline & & $\mathrm{RD}$ & Total annual wet days (rainfall $\geq 1 \mathrm{~mm}$ ) & days \\
\hline & \multirow{3}{*}{$\begin{array}{l}\text { Length of the rainy } \\
\text { season }\end{array}$} & Lrs & Length of rs & days \\
\hline & & Srs & Starting day of rs & day \\
\hline & & Ers & Ending day of rs & day \\
\hline & \multirow[t]{4}{*}{$\begin{array}{l}\text { Rainfall events during } \\
\text { the dry season }\end{array}$} & RDds & $\begin{array}{l}\text { Number of days with rainfall during } \\
\text { ds (rainfall } \geq 1 \mathrm{~mm} \text { ) }\end{array}$ & days \\
\hline & & TOTRds & Total of rainfall during ds & $\mathrm{mm}$ \\
\hline & & PRds & Percentage of rainfall during ds & $\%$ \\
\hline & & Heug5 & Number of days with rainfall $\geq 5 \mathrm{~mm}$ during ds & days \\
\hline & \multirow[t]{2}{*}{ Dry spells } & DDrs & Number of dry days during rs & days \\
\hline & & CDDrs & $\begin{array}{l}\text { Maximum number of consecutive } \\
\text { dry days during rs }\end{array}$ & days \\
\hline & \multirow[t]{7}{*}{ Rainfall intensity } & SDII & Average rainfall by wet day & $\mathrm{mm} /$ day \\
\hline & & R10 & Annual number of days with rainfall $\geq 10 \mathrm{~mm}$ & days \\
\hline & & R10p & $\begin{array}{l}\text { Percentage of annual rainfall from days with rainfall } \\
\geq 10 \mathrm{~mm}\end{array}$ & $\%$ \\
\hline & & $\mathrm{R} 20$ & Annual number of days with rainfall $\geq 20 \mathrm{~mm}$ & days \\
\hline & & $\mathrm{R} 20 \mathrm{p}$ & $\begin{array}{l}\text { Percentage of annual rainfall from } \\
\text { days with rainfall } \geq 20 \mathrm{~mm}\end{array}$ & $\%$ \\
\hline & & Rmax & Annual maximum 1-day rainfall & $\mathrm{mm}$ \\
\hline & & $R \operatorname{maxp}$ & $\begin{array}{l}\text { Percentage of annual rainfall from } \\
\text { maximum 1-day rainfall }\end{array}$ & $\%$ \\
\hline \multirow[t]{11}{*}{ Temperature } & \multirow[t]{5}{*}{$\begin{array}{l}\text { Intensity during } \\
\text { the dry season }\end{array}$} & TNds & $\begin{array}{l}\text { Average value of daily minimal } \\
\text { temperature during ds } \\
\text { Average value of daily maximal } \\
\text { temperature during ds }\end{array}$ & ${ }^{\circ} \mathrm{C}$ \\
\hline & & \multirow[t]{2}{*}{ TXds } & $\begin{array}{l}\text { Average value of daily mean } \\
\text { temperature during ds }\end{array}$ & ${ }^{\circ} \mathrm{C}$ \\
\hline & & & Daily temperature range during $\mathrm{ds}$ & \\
\hline & & Tds & & ${ }^{\circ} \mathrm{C}$ \\
\hline & & DTRds & & ${ }^{\circ} \mathrm{C}$ \\
\hline & \multirow[t]{6}{*}{$\begin{array}{l}\text { Intensity during } \\
\text { the rainy season }\end{array}$} & \multirow[t]{2}{*}{ TNrs } & $\begin{array}{l}\text { Average value of daily minimal } \\
\text { temperature during rs }\end{array}$ & ${ }^{\circ} \mathrm{C}$ \\
\hline & & & $\begin{array}{l}\text { Average value of daily maximal } \\
\text { temperature during rs }\end{array}$ & \\
\hline & & \multirow[t]{2}{*}{ TXrs } & $\begin{array}{l}\text { Average value of daily mean } \\
\text { temperature during rs }\end{array}$ & ${ }^{\circ} \mathrm{C}$ \\
\hline & & & Daily temperature range during $\mathrm{rs}$ & \\
\hline & & Trs & & ${ }^{\circ} \mathrm{C}$ \\
\hline & & DTRrs & & ${ }^{\circ} \mathrm{C}$ \\
\hline
\end{tabular}

- The daily time-step allowed us to calculate indicators linked to season. In previous studies based on the same perception data as we used here, climate change perceptions had been compared with climatic trends but due to limited data availability, this was only possible for rainfall amounts and dry spells (Mertz et al. 2012; Zampaligré et al. 2014). 
Moreover, the use of climate estimates instead of meteorological stations' data was presented as a limitation in some studies (e.g. Dickinson et al. 2017; Kosmowski et al. 2016).

\subsection{Method}

A set of 20 rainfall indices were defined to be consistent with the 5 questions rural dwellers were asked about rainfall change perception (Table 1). Some of them (TOTR, RD, SDII, R10, R10p, R20, R20p, Rmax and Rmaxp) were based on climate indices developed by the Expert Team on Climate Change Detection Monitoring and Indices (ETCCDMI) and calculated with the RClimDex software (Zhang and Yang 2004). In addition, we developed several indices calculated by season (see Table 1). For this, the method of Sivakumar (1988) was used to determine the start and the end of the rainy season for each year of the study period. The first day of the rainy season at a given location is the date after May 1 when total rainfall over three consecutive days is at least $20 \mathrm{~mm}$, with no dry spell exceeding 7 days during the following 30 days. The last day is after 1 September if no rain occurs for a period of 20 days following this date. The values of indices related to season were then calculated for each year.

For temperature indices, we used the definition of average rainfall season in the country (May 1 to October 1) (Lodoun et al. 2013) and calculated the average daily minimal, maximal and mean temperatures as well as the average daily temperature range separately for each season, that is to say 8 indices (Table 1). There were no missing data in the database, which made it possible to analyse trends.

Trend coefficients were calculated using Spearman's rank correlation over the 1988-2007 period to be in agreement with the survey. We used two significance $p$ level $(p<0.05$ and $p<0.1$ ) to analyse the hypothesis that the slope was equal or different to 0 . Each trend was categorized in six classes according to the slope (positive or negative) and statistical significance (not significant $(p \geq 0.1)$, moderate $(p<0.1)$ or significant $(p<0.05))$. No significant trends were considered as a stability of the parameter. Then, we qualitatively compared climate trends with climate change perceptions by the surveyed population.

\subsection{Results}

\subsubsection{Climate change and variability as perceived by the surveyed rural dwellers}

In Burkina Faso, rural dwellers perceived deteriorating climate conditions over the period 1988-2007. The main agreement about rainfall change (86.3\%) was the shortening of the rainy season (Fig. 2). Only $7 \%$ reported an increase in the duration of the rainy season and $2.5 \%$ perceived stability. Most of the respondents (83.9\%) also cited a decrease in the total annual rainfall. In addition to these perceptions reflecting rainfall shortages, other perceptions were related to more erratic rains. About $85 \%$ of respondents observed an increase in the length of dry spells during the rainy season and individual rainfall events during the dry season decreased according to $68.9 \%$ of respondents. Concerning the intensity of rainfall events, opinions were more divided, with $65 \%$ of respondents having reported a declining trend and $27 \%$ having reported an increase. Site 4 (see Fig. 1) presented the greatest homogeneity in responses (Table 2). More than $92 \%$ of respondents mentioned a decrease in the total annual rainfall, the length of the rainy season and the intensity of rainfall events and an increase in the length of dry spells during the rainy season. Moreover, more than $90 \%$ reported fewer rainfall events during the dry season. In site 3, more than $90 \%$ of the respondents agreed that the total 
annual rainfall, the length of the rainy season and the occurrence of rainfall events during the dry season had decreased (Table 2). Nearly $87 \%$ of the respondents also observed an extension in the length of dry spells during the rainy season. Perceptions were more variable concerning the intensity of rainfall events. In the driest surveyed sites (sites 1 and 2), opinions were more

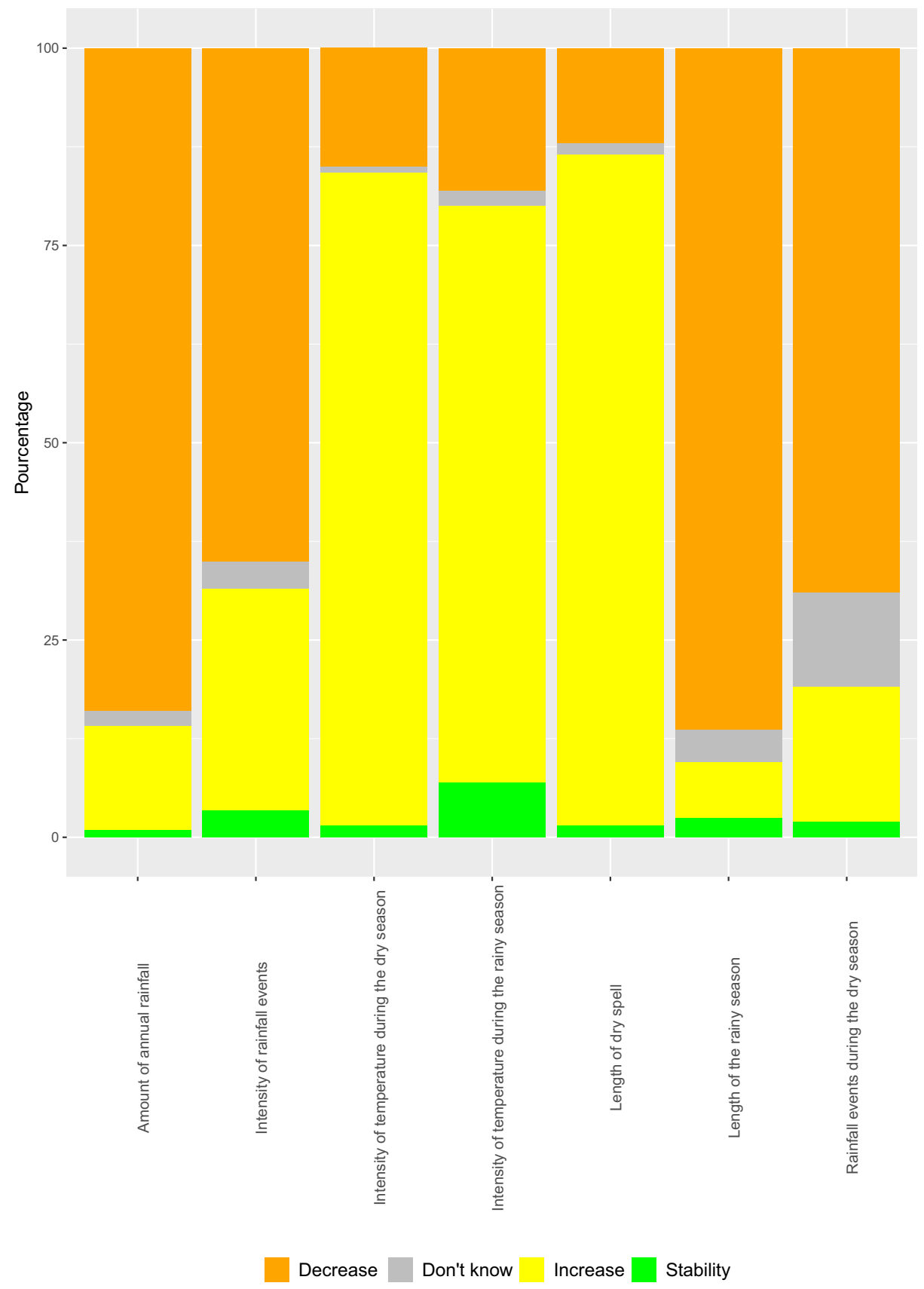

Fig. 2 Perceptions of change in rainfall and temperature in the four surveyed sites combined $(N=383)$ 
Table 2 Perceptions of change in rainfall and temperature by surveyed sites ( - decrease, $=$ stability, + increase, $\%$ of respondents - if the total is not $100 \%$, the rest is in the category 'do not know')

\begin{tabular}{|c|c|c|c|c|c|c|c|c|c|c|c|c|}
\hline \multirow[t]{2}{*}{ Perception (from AMMA survey) } & \multicolumn{3}{|c|}{$\begin{array}{l}\text { Oudalan } \\
(N=81), \text { site } 1\end{array}$} & \multicolumn{3}{|c|}{$\begin{array}{l}\text { Tougou }(N=98) \text {, } \\
\text { site } 2\end{array}$} & \multicolumn{3}{|c|}{$\begin{array}{l}\text { Ziga }(N=99), \\
\text { site } 3\end{array}$} & \multicolumn{3}{|c|}{$\begin{array}{l}\text { Dano } \\
(N=105), \text { site } \\
4\end{array}$} \\
\hline & - & $=$ & + & - & $=$ & + & - & $=$ & + & - & $=$ & + \\
\hline Amount of annual rainfall & 75.3 & 1.3 & 20.8 & 63.4 & 4.3 & 31.2 & 98 & 0 & 0 & 95.2 & 0 & 1 \\
\hline Length of the rainy season & 64.9 & 3.9 & 16.9 & 80.6 & 6.5 & 9.7 & 98 & 0 & 0 & 96.2 & 0 & 1 \\
\hline Rainfall events during the dry season & 35.1 & 1.3 & 26 & 44.1 & 7.5 & 40.9 & 90 & 0 & 0 & 96.2 & 0 & 1 \\
\hline Dry spells during the rainy season & 26 & 0 & 71.4 & 9.7 & 2.2 & 84.9 & 0.8 & 0.4 & 86.9 & 2.9 & 0 & 96.2 \\
\hline Intensity of rainfall events & 64.5 & 0 & 28.9 & 28.6 & 8.8 & 60.4 & 69.7 & 7.1 & 19.2 & 92.3 & 0 & 2.9 \\
\hline $\begin{array}{l}\text { Intensity of temperature during } \\
\text { the dry season }\end{array}$ & 26 & 1.3 & 70.1 & 11.8 & 4.3 & 83.9 & 11.1 & 1 & 86.9 & 4.8 & 0 & 95.2 \\
\hline $\begin{array}{l}\text { Intensity of temperature during } \\
\text { the rainy season }\end{array}$ & 41.6 & 7.8 & 44.2 & 18.3 & 21.5 & 57 & 16.2 & 2 & 80.8 & 1 & 0 & 99 \\
\hline
\end{tabular}

divided (Table 2). The decrease in the total annual rainfall, the shortening of the rainy season and the extension of the length of dry spells during the rainy season were also the dominant perceptions but it was less unanimous than in sites 3 and 4 . Opinions were sharply divided about rainfall events during the dry season and to a lesser extent about the intensity of rainfall events. In site $1,64.5 \%$ of the respondents perceived a decrease in the intensity of rainfall events, against $28.9 \%$ who reported an increase. Trends were reversed in site 2.

Results about perceptions of change in temperature clearly showed warming perceived by the surveyed population over the study period (Fig. 2). An increase in temperature during the dry season was reported by $85 \%$ of the respondents and by $72.4 \%$ during the rainy season across the four sites. The share of respondents who mentioned stability in these parameters is greater than for factors related to rainfall but remains low. As for the perceptions of change in rainfall, perceptions relative to temperature change were more homogeneous in site 4 than in other sites (Table 2).

\subsubsection{Climate change and variability observed in meteorological data}

There were few significant trends in rainfall indices over the 1988-2007 period. Only the station of Gorom-Gorom (site 1) recorded a significant $(p<0.05)$ positive trend for the total annual rainfall (TOTR), the average rainfall on wet days (SDII) and the annual number of days with rainfall amounting to $\geq 20 \mathrm{~mm}$ (R20). The stations of sites 1 and 2 exhibited a moderate $(p<0.1)$ positive trend for the percentage of annual rainfall from days with rainfall $\geq 20 \mathrm{~mm}$ (R20p). Moreover, the percentage of annual rainfall from days with rainfall $\geq 10 \mathrm{~mm}$ (R10p) also showed a positive increase at Gorom-Gorom. These significant positive trends indicated an increase in the total annual rainfall and in rainfall intensity in the north of the country. At the station of Ouahigouya (site 2), the significant trend illustrated the growing importance of heavy rains in the total annual rainfall. No index had a constant sign for all the studied stations and the observation of opposite signs was common for two stations in the same region. But the slope coefficients were not significant for most indices and stations, which indicated a stability of the conditions over 1988-2007. Actually, the total annual rainfall in West Africa had generally decreased during the latter decades of the twentieth century (Nicholson 2000) before increasing from the 1990s (Lebel and Ali 2009; Ozer et al. 2003). 
Contrary to the trends in rainfall, trends observed in temperature were mostly significant $(p<0.05)$ for the two seasons. However, there was disparity among stations because only four indices (TNds, TXds, Tds and TNrs) recorded the same trend everywhere. The increase in minimal temperature was higher than in maximal temperature. Therefore, trends in daily temperature ranges had often been negative and more significant in the northern and southern regions than in the central site. The increase in minimal temperature was more marked during the dry season in the driest regions (an increase of nearly $2{ }^{\circ} \mathrm{C}$ recorded in site 1 over the study period) and during the rainy season in the wettest regions $\left(+1^{\circ} \mathrm{C}\right.$ recorded in site 4$)$.

\subsubsection{Comparison between perceptions and climate trends}

Our results showed a good fit between perceptions of changes in temperature by rural dwellers of Burkina Faso and recorded trends observed in temperatures (Fig. 3). It is interesting to note however that this increased temperature, while matching with climate observation, has not been perceived by all respondents living in the same town (Table 2). As seen in the literature, the number of respondents who perceived increasing temperatures is indeed a majority but lower than the number of respondents who perceived a decrease in total rainfall and a shortening of the rainy season (Fig. 2).

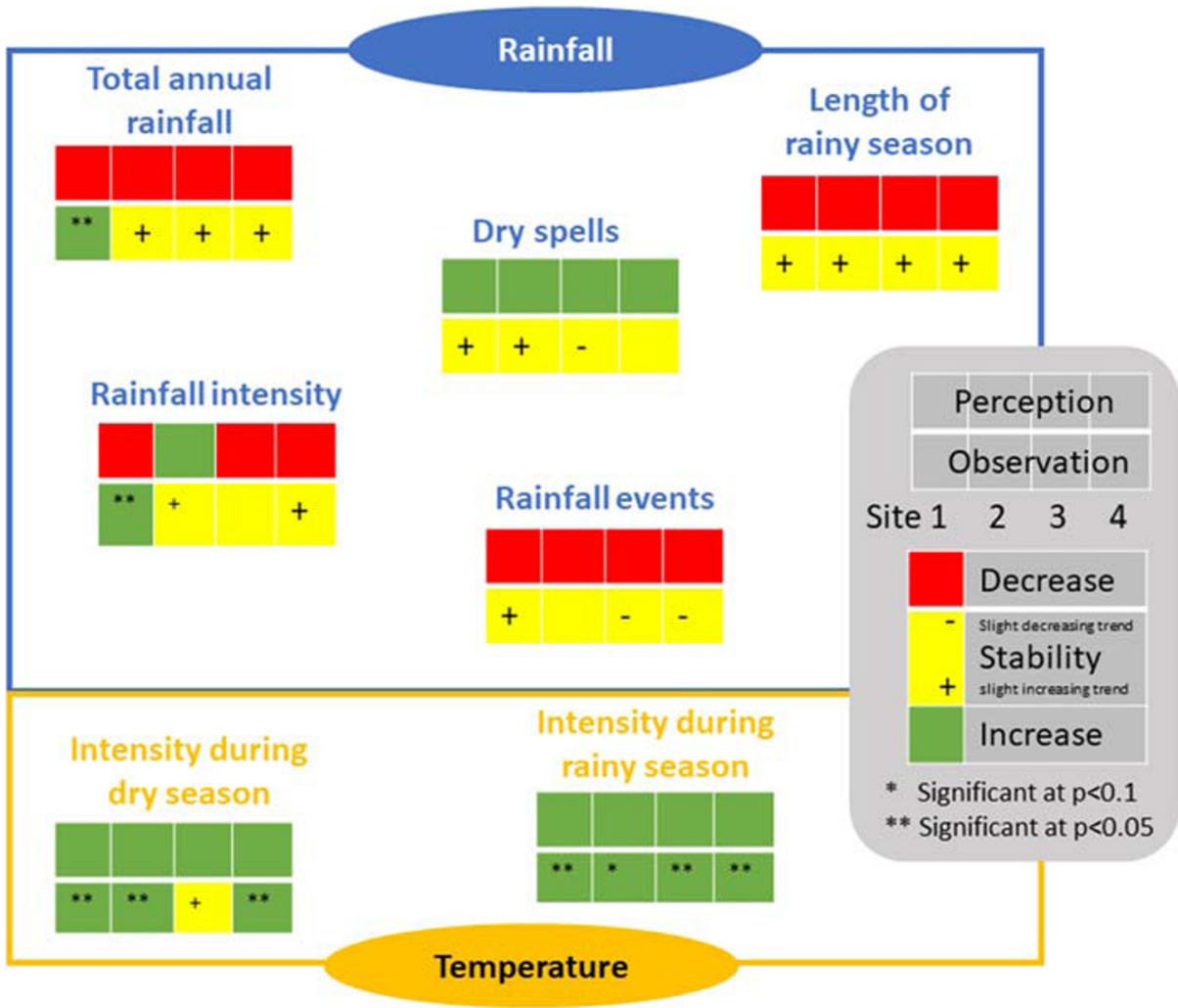

Fig. 3 Summary of the comparison between change perceptions and observed change in Burkina Faso over the 1988-2007 period 
We noted inconsistencies between the rainfall change perceptions of rural dwellers and calculated rainfall trends in all the sites, whatever the index considered (Fig. 3). These were the most visible in site 1 where significant increases in the total annual rainfall and in the rainfall intensity were observed while people perceived decreases. In the other sites, the signs of the trends were also often in opposition to the perceptions but the slope coefficients were low, which further illustrated a stability of the weather conditions. Consistencies between perceptions and trends were observed for the rainfall events during the dry season and dry spells during the rainy season but the slope coefficients were not significant. Rainfall change perceptions (a decline of rainfall conditions) were more pronounced than recorded trends, mostly non-significant. As in other studies, most of the respondents reported that the climate had changed for the worse, even if the used methodology to study perception varies from one study to another (Nielsen and D'haen 2014).

\subsubsection{The importance of migration as an adaptation strategy to climate change}

In the AMMA database, more than $45 \%$ of households have members who were engaged in temporary migration at the time of the survey in 2008 and nearly $14 \%$ of households had permanent migrants. In total, 28 households $(7.3 \%)$ had both permanent and temporary migrants and less than half of the households (48.3\%) had no migrant member. Poverty was the leading cause of migration mentioned by respondents $(78.1 \%)$ while rainfall deficit was stated by only $1.6 \%$ of households. This supports the results of Romankiewicz and Doevenspeck (2015) showing that when explicit questions about the possible linkages between environment and migration are avoided, environmental stress was not mentioned as a key driver of migration.

For 53 households (13.8\%), migration was seen as a positive consequence of climate variability. The increase of income is the most important aspect mentioned by respondents but money transfers and acquisition of knowledge that can be implemented in the origin area are other positive effects of migration (Cissé et al. 2010). It is also a means to reduce pressure on households' resources (Roncoli et al. 2002). On the other hand, 40 households (10.4\%) considered that migration is a negative consequence of climate variability. Because of adverse climate conditions, farmers have to migrate despite their desire to remain in their own communities (Barbier et al. 2009). Loss of labour force in the community of origin and acculturation are the main negative points of migration (Rasmussen et al. 2012).

In response to future changes in rainfall, migration is rarely the first adaptation strategy stated by the respondents but the intention to migrate occupies an important place. In the case of drought, rural dwellers plan first to sell livestock and to decrease food intake but respondents generally mentioned several strategies. Migration is cited as the first strategy by $12.7 \%$ of the respondents and, in total, $17.5 \%$ of the respondents have the intention to resort to temporary migration in response to drought. In the case of a drier climate, the first two strategies planned by respondents are to seek new crop varieties and to sell livestock. About $10 \%$ of the respondents mentioned temporary migration and $26 \%$ permanent migration; these would be the first strategy respectively for $7.8 \%$ and $6.9 \%$ of households. The intention to migrate is lower in response to a wetter climate since only $2.4 \%$ and $1.6 \%$ of the respondents claimed that they would migrate temporarily or permanently. Seeking new crop varieties and increase the cropland area would be the main strategies adopted in this case.

Counting only once the people who answered positively to both questions about the intention to migrate temporarily in a situation of rainfall deficit (drought and/or drier climate), 
$28.5 \%$ of the respondents planned to adopt this strategy. This figure increases by $13 \%$ taking into account the intention to migrate permanently in response to a drier climate. According to the fact that more than $40 \%$ of the surveyed people in Burkina Faso claimed to have the intention to resort to temporary or permanent migration if the rainfall conditions worsen, this might lead to a change in migration patterns in the future, notably from predominantly temporary to more permanent migration. Moreover, knowing that most of the respondents already considered degradation of rainfall conditions over the period 1988-2007 while it is not clearly observed in the climate data, a significant increase in migration could occur faster than expected, if climate predictions hold.

\section{Discussion}

\subsection{Potential sources of bias remaining in our empirical study}

We optimized study conditions to compare perceptions of climate change and variability with climate trends in Burkina Faso but there were still shortcomings. Firstly, rainfalls in the Sahel are highly variable in space (Hulme 2001; Sivakumar and Hatfield 1990). It can rain in one village while another $5 \mathrm{~km}$ away remains dry. Hence, the use of data from exactly the same spot when comparing perceptions with scientifically observed trends would be more precise. Such data was unfortunately not available for our study. Secondly, a period of 20 years is short — climatologically speaking — to detect statistical trends in temporal meteorological series but relevant concerning the 'memory of surveyed people'. Also, the stay duration of respondents in communities would be an important piece of information to ascertain the reliability of their perceptions but we did not have these data. Thirdly, climate indices were relatively stable over the period 1988-2007 in comparison with trends over the long-term or with trends over other short periods, notably the 20-year dry period 1970-1989 (de Longueville et al. 2016; Lebel and Ali 2009). If respondents had no good point(s) of reference for considering only the recent period, it is possible that they were influenced by the fact that they intuitively found the weather better in the past (Mertz et al. 2012). It is also argued that people seem to recall extreme weather events more easily than gradual trends and recent experience appears to influence the perceptions of long-term trends (Howe et al. 2014). Moreover, perceptions that there has been declining rainfall (not observed in climate trends) may be the impact of higher temperature, higher evapotranspiration and greater water stress (Osbahr et al. 2011). Fourthly, it would be interesting to analyse the demographic characteristics of respondents (age, gender, education level, working category...) because it might very likely influence their answers but these data were not collected during the survey. Finally, we cannot exclude several elements which might contribute to a pessimistic perception. Respondents may think that painting a gloomy picture of the environment could attract funding for local projects (Nielsen et al. 2012). Perceptions may also be strongly influenced by media stories that tend to focus on negative developments in the environment (Mertz et al. 2012; Soglo and Nonvide 2019).

\subsection{Local perception of rainfall change is not a reflection of rainfall change and variability}

Despite these potential biases, our results highlight that perceptions of rainfall change and variability by the surveyed population are not a reflection of the change and variability 
measured in rainfall data. Rural dwellers' perceptions of climate change varied considerably and were not systematically consistent with the scientifically observed trends, lending support to the idea that other personal and environmental factors are important for determining climate change perceptions (Niles and Mueller 2016). This matches with the affirmation that local people observe different variables than scientists (Marin and Berkes 2013) and strengthens the conclusions drawn by Roncoli (2006) suggesting that farmers think about rainfall as a process rather than a quantity. At an individual level, perceptions of environmental change depend not only on an individual's exposure to environmental events but also on his/her adaptive capacity. This is perhaps reflected in our analysis considering that even within the exact same location people perceive rainfall changes differently. Kosmowski et al. (2016) similarly demonstrated differences of perception between climate-sensitive and non-climate-sensitive households confirming that farmers do not perceive climate in meteorological terms but rather as it affects agricultural activities (Akponikpè et al. 2010). As such, meteorological data represent people's exposure to climate change at the community level, while perceptions of climate change are linked to experienced climatic impacts (Leclerc et al. 2013). The analysis of the household survey carried out in the AMMA project shows that nearly $75 \%$ of the respondents reported negative impacts of these changes on agriculture and $65 \%$ on livestock breeding over the study period even if grain yields have been increasing during this period. Moreover, other factors than climate change, such as population growth and environmental degradation, contribute to

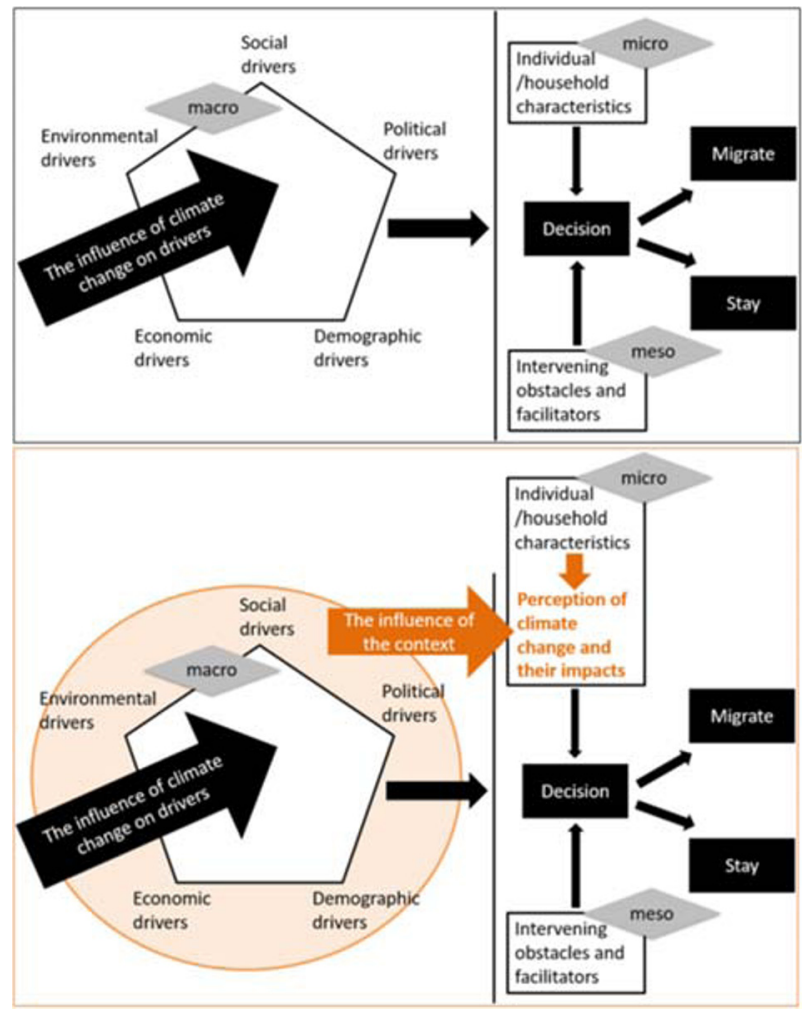

Fig. 4 (Above) Simplified version of the conceptual framework showing the influence of climate change on drivers of migration (adapted from Black et al. 2011). (Below) Adapted version including the notion of perception (in orange) 
hindering socio-economic activities and to worsening living conditions (Rasmussen et al. 2012).

\subsection{Consequences for future research on environmental migration}

Over the last three decades, an increasing number of empirical studies have highlighted the role of climate change/variation - as other drivers - in migration (see Fig. 4, above). More recently, a few studies, using a qualitative/ethnographic approach, are rather based on data on the perception of climate change (Borderon et al. 2018; Piguet 2010). These studies empirically showed that the perceptions of climate change/variation can influence the decision to migrate. Our exhaustive literature review focusing on perceptions of climate change in West Africa, completed by an empirical comparison between perceptions of rural dwellers in Burkina Faso and scientifically observed trends, allows us to confirm that rural populations of this region perceive climate change and variation but not necessarily in consistency with observations. We deduce that perception data cannot replace climate data (and vice versa) in research on the environment-migration nexus and that both climate trends and perceptions should be considered. The current context of the West African region, with poor socioeconomic conditions due to other co-occurring factors than climate change (demographic pressure, environmental degradation) can explain why most of the respondents reported that climate change had been worse than what actually emerges from our analysis of meteorological data. Consequently, we suggest that integrating climate data and data on rainfall change perceptions in future research could add new significant value in the understanding of household decision to move or not, notably in West Africa. One way would be based on including the notion of perception in the conceptual framework of Black et al. (2011) (Fig. 4, below) and to test it empirically.

\section{Conclusion}

In the literature, there is a general consensus that the West African populations perceive climate change and more than half of the studies conducted on this topic in the region concluded to consistency between these perceptions and observed climate trends. Our empirical study provides good evidence of inconsistency between rainfall change perception and climate observations in Burkina Faso. Noting potential biases and lacks relating to used data and method, we concluded however that perceptions of rainfall change are not a reflection of scientifically observed trends. While researchers increasingly consider the effects of climate change on migration, the results of this study highlight the importance of taking into account people's perceptions of climate change as it affects their adaptation responses. Considering this, we argue that it would be possible to improve the understanding of the decision to migrate on the scale of the household in West Africa by considering jointly climate data and data about perceptions of climate change in future research. This approach would require us to transcend disciplinary boundaries (Nielsen and D'haen 2014; Popke 2016). The results could contribute to a better understanding of the future potential climatic impacts on the decisions to migrate and prove useful in the elaboration of adaptation programs and policies when developing answers to climate change. 
Acknowledgments The authors gratefully acknowledge the Direction Générale de la Météorologie du Burkina Faso for providing climate data, Christine Pagnoulle for English proofreading and the three anonymous reviewers for their insightful reading and constructive suggestions.

Funding information This research has received funding from the European Union Seventh Framework Programme FP7/2007-2013 under grant agreement no. 603864.

\section{References}

Adger WN, Dessai S, Goulden M et al (2009) Are there social limits to adaptation to climate change? Clim Chang 93:335-354. https://doi.org/10.1007/s10584-008-9520-z

Afifi T, Milan A, Etzold B, Schraven B, Rademacher-Schulz C, Sakdapolrak P, Reif A, van der Geest K, Warner $\mathrm{K}$ (2016) Human mobility in response to rainfall variability: opportunities for migration as a successful adaptation strategy in eight case studies. Migr Dev 5:254-274. https://doi.org/10.1080 /21632324.2015.1022974

Akponikpè PBI, Johnston P, Agbossou KE (2010) Farmers' perceptions of climate change and adaptation strategies in sub-Sahara West Africa. 2nd International Conference on Climate, Sustainability and Development in Arid Regions, 16-20 August 2010, Fortaleza-Ceara, Brazil

Alessa L, Kliskey A, Williams P, Barton M (2008) Perception of change in freshwater in remote resourcedependent Arctic communities. Global Environ Chang 18:153-164. https://doi.org/10.1016/j. gloenvcha.2007.05.007

Ayanlade A, Radeny M, Morton JF (2017) Comparing smallholder farmers' perception of climate change with meteorological data: a case study from southwestern Nigeria. Weather Clim Extrem 15:24-33. https:/doi. org/10.1016/j.wace.2016.12.001

Barbier B, Yacouba H, Karambiri H, Zoromé M, Somé B (2009) Human vulnerability to climate variability in the Sahel: farmers' adaptation strategies in northern Burkina Faso. Environ Manag 43:790-803. https://oi. org/10.1007/s00267-008-9237-9

Black R, Adger WN, Arnell NW, Dercon S, Geddes A, Thomas D (2011) The effect of environmental change on human migration. Global Environ Chang 21:S3-S11. https://doi.org/10.1016/j.gloenvcha.2011.10.001

Black R, Arnell NW, Adger WN, Thomas D, Geddes A (2013) Migration, immobility and displacement outcomes following extreme events. Environ Sci Pol 27:s32-S43. https://doi.org/10.1016/j. envsci.2012.09.001

Borderon M, Sakdapolrak P, Muttarak R, Kebede E, Pagogna R, Sporer E (2018) A systematic review of empirical evidence on migration influenced by environmental change in Africa. IIASA Working Paper. Laxenburg, Austria: WP-18-003. http://pure.iiasa.ac.at/id/eprint/15382/. Accessed 15 Jul 2019

Brüning L, Piguet E (2018) Changements environnementaux et migration en Afrique de l'Ouest. Une revue des études de cas Belgeo Revue belge de géographie 1. https://doi.org/10.4000/belgeo.28836

Bryan E, Deressa TT, Gbetibouo GA, Ringler C (2009) Adaptation to climate change in Ethiopia and South Africa: options and constraints. Environ Sci Pol 12:413-426. https://doi.org/10.1016/j.envsci.2008.11.002

Byg A, Salick J (2009) Local perspectives on a global phenomenon - climate change in eastern Tibetan villages. Global Environ Chang 19:156-166. https://doi.org/10.1016/j.gloenvcha.2009.01.010

Cissé P, Zorom M, Barbier B, Maiga A (2010) Les migrations, une stratégie d'adaptation à la variabilité climatique en zones sahéliennes. Revue de Géographie du Laboratoire Leïdi 8:184-196

Cordell DD, Gregory JW, Piché V (1996) Hoe and wage: a social history of a circular migration system in West Africa. Westview press, Boulder

D'haen SAL, Nielsen JØ, Lambin EF (2011) Beyond local climate: rainfall variability as a determinant of household nonfarm activities in contemporary rural Burkina Faso. Clim Dev 6:144-165. https://doi. org/10.1080/17565529.2013.867246

de Longueville F, Hountondji YC, Kindo I, Gemenne F, Ozer P (2016) Long-term analysis of rainfall and temperature data in Burkina Faso (1950-2013). Int J Climatol 36:4393-4405. https://doi.org/10.1002 /joc. 4640

de Longueville F, Zhu Y, Henry S (2019) Direct and indirect impacts of environmental factors on migration in Burkina Faso: application of structural equation modelling. Pop Environ 40:456-479. https://doi. org/10.1007/s11111-019-00320-x

de Sherbinin A (2011) The biophysical and geographical correlates of child malnutrition in Africa. Popul Space Place 17:27-46. https://doi.org/10.1002/psp.599 
Dickinson KL, Monaghan AJ, Rivera IJ et al (2017) Changing weather and climate in northern Ghana: comparison of local perceptions with meteorological and land cover data. Reg Environ Chang 17:915928. https://doi.org/10.1007/s10113-016-1082-4

Eklund L, Romankiewicz C, Brandt M, Doevenspeck M, Samimi C (2016) Data and methods in the environment-migration nexus: a scale perspective. Die Erde J Geogr Soc Berl 147:139-152

Fosu-Mensah BY, Vlek PL, MacCarthy DS (2012) Farmers' perception and adaptation to climate change: a case study of Sekyedumase district in Ghana. Environ Dev Sustai 14:495-505. https://doi.org/10.1007/s10668012-9339-7

Gray C, Wise E (2016) Country-specific effects of climate variability on human migration. Clim Chang 135:555568. https://doi.org/10.1007/s10584-015-1592-y

Henry S, Piché V, Ouédraogo D, Lambin EF (2004) Descriptive analysis of the individual migratory pathways according to environmental typologies. Pop Environ 25:397-422

Howe PD, Thaker J, Leiserowitz A (2014) Public perceptions of rainfall change in India. Clim Chang 127:211225. https://doi.org/10.1007/s10584-014-1245-6

Hulme M (2001) Climatic perspectives on Sahelian desiccation: 1973-1998. Global Environ Chang 11:19-29. https://doi.org/10.1016/S0959-3780(00)00042-X

Hunter L (2005) Migration and environmental hazards. Pop Environ 26:273-302. https://doi.org/10.1007 /s11111-005-3343-X

Hunter LM, Luna JK, Norton RM (2015) Environmental dimensions of migration. Annu Rev Sociol 41:377397. https://doi.org/10.1146/annurev-soc-073014-112223

Izazola H, Martinez C, Marquette C (1998) Environmental perceptions, social class and demographic change in Mexico City: a comparative approach. Environ Urban 10:107-118

Juana JS, Kahaka Z, Okurut FN (2013) Farmers' perceptions and adaptations to climate change in sub-Sahara Africa: a synthesis of empirical studies and implications for public policy in African agriculture. J Agr Sci 5: 121-135. https://doi.org/10.5539/jas.v5n4p121

Kaczan DJ, Orgill-Meyer J (2019) The impact of climate change on migration: a synthesis of recent empirical insights. Clim Chang:1-20. https://doi.org/10.1007/s10584-019-02560-0

Kima SA, Okhimamhe AA, Kiema A, Zampaligré N, Sule I (2015) Adapting to the impacts of climate change in the sub-humid zone of Burkina Faso, West Africa: perceptions of agro-pastoralists. Pastoralism 5:16. https://doi.org/10.1186/s13570-015-0034-9

Kosmowski F, Leblois A, Sultan B (2016) Perceptions of recent rainfall changes in Niger: a comparison between climate-sensitive and non-climate sensitive households. Clim Chang 135:227-241. https://doi.org/10.1007 /s10584-015-1562-4

Koubi V, Spilker G, Schaffer L, Böhmelt T (2016a) The role of environmental perceptions in migration decisionmaking: evidence from both migrants and non-migrants in five developing countries. Pop Environ 38:134 163. https://doi.org/10.1007/s11111-016-0258-7

Koubi V, Stoll S, Spiker G (2016b) Environmental change and migration decisions. Clim Chang 138:439-451. https://doi.org/10.1007/s10584-016-1767-1

Lebel T, Ali A (2009) Recent trends in the central and western Sahel rainfall regime (1990-2007). J Hydrol 375 : 52-64. https://doi.org/10.1016/j.jhydrol.2008.11.030

Leclerc C, Mwongera C, Camberlin P, Boyard-Micheau J (2013) Indigenous past climate knowledge as cultural built-in object and its accuracy. Ecol Soc 18:22. https://doi.org/10.5751/ES-05896-180422

Lodoun T, Giannini A, Traore PS et al (2013) Changes in seasonal descriptors of precipitation in Burkina Faso associated with late 20th century drought and recovery in West Africa. Environ Dev 5:96-108. https://doi. org/10.1016/j.envdev.2012.11.010

López S, Jung JK, López MF (2017) A hybrid-epistemological approach to climate change research: linking scientific and smallholder knowledge systems in the Ecuadorian Andes. Anthropocene 17:30-45. https://doi. org/10.1016/j.ancene.2017.01.001

Lu M (1999) Do people move when they say they will? Inconsistencies in individual migration behavior. Pop Environ 20:467-488

Macleod L (1996) The migration intentions of young people in Ullapool. Scottish Affairs 15:70-82

Marin A, Berkes F (2013) Local people's accounts of climate change: to what extent are they influenced by the media? WIRES Clim Change 4:1-8. https://doi.org/10.1002/wcc.199

Mertz O, Mbow C, Nielsen JØ et al (2010) Climate factors play a limited role for past adaptation strategies in West Africa. Ecol Soc 15(4):25 http:/www.ecologyandsociety.org/vol15/iss4/art25/. Accessed 14 Sept 2019

Mertz O, Mbow C, Reenberg A et al (2011) Adaptation strategies and climate vulnerability in the SudanoSahelian region of West Africa. Atmosph Sci Lett 12:104-108. https://doi.org/10.1002/asl.314

Mertz O, D'haen SAL, Maiga A et al (2012) Climate variability and environmental stress in the Sudan-Sahel zone of West Africa. Ambio 41:380-392. https://doi.org/10.1007/s13280-011-0231-8 
Meze-Hausken E (2004) Contrasting climate variability and meteorological drought with perceived drought and climate change in northern Ethiopia. Clim Res 27:19-31. https://doi.org/10.3354/cr027019

Neumann K, Hilderink H (2015) Opportunities and challenges for investigating the environment-migration nexus. Hum Ecol 43:309-322. https://doi.org/10.1007/s10745-015-9733-5

Nicholson SE (2000) The nature of rainfall variability over Africa on time scales of decades to millenia. Glob Planet Chang 26:137-158. https://doi.org/10.1016/S0921-8181(00)00040-0

Nielsen JØ, D’haen SAL (2014) Asking about climate change: reflections on methodology in qualitative climate change research published in global environmental change since 2000. Global Environ Chang 24:402-409. https://doi.org/10.1016/j.gloenvcha.2013.10.006

Nielsen JØ, Reenberg A (2010a) Cultural barriers to climate change adaptation: a case study from northern Burkina Faso. Global Environ Chang 20:142-152. https://doi.org/10.1016/j.gloenvcha.2009.10.002

Nielsen JØ, Reenberg A (2010b) Temporality and the problem with singling out climate as a current driver of change in a small West African village. J Arid Environ 74:464-474. https://doi.org/10.1080 $/ 17565529.2012 .660357$

Nielsen JØ, D'haen SAL, Reenberg A (2012) Adaptation to climate change as a development project: a case study from northern Burkina Faso. Clim Dev 4:16-25. https://doi.org/10.1080/17565529.2012.660357

Niles MT, Mueller ND (2016) Farmer perceptions of climate change: associations with observed temperature and precipitation trends, irrigation, and climate beliefs. Global Environ Chang 39:133-142. https://doi. org/10.1016/j.gloenvcha.2016.05.002

Obokata R, Veronis L, McLeman R (2014) Empirical research on international environmental migration: a systematic review. Pop Environ 36:111-135. https://doi.org/10.1007/s11111-014-0210-7

Osbahr H, Dorward P, Stern R, Cooper S (2011) Supporting agricultural innovation in Uganda to respond to climate risk: linking climate change and variability with farmer perceptions. Exp Agr 47:293-316

Ozer P, Perrin D (2014) Eau et changement climatique. Tendances et perceptions en Afrique de l'Ouest. In: Ballouche A, Taïbi NA (eds) Eau, milieux et aménagement Une recherche au service des territoires. Presses universitaires d'Angers, Angers, pp 227-245

Ozer P, Erpicum M, Demaree G, Vandiepenbeeck M (2003) The Sahelian drought may have ended during the 1990s. Hydrolog Sci J 48:489-492

Piguet E (2010) Linking climate change, environmental degradation, and migration: a methodological overview. WIRES Clim Change1(4): 517-524

Popke J (2016) Researching the hybrid geographies of climate change: reflections from the field. Area 48:2-6. DOI:10.111/area. 12220

Rademacher-Schulz C, Schraven B, Mahama ES (2014) Time matters: shifting seasonal migration in Northern Ghana in response to rainfall variability and food insecurity. Clim Dev 6:46-52. https://doi.org/10.1080 $/ 17565529.2013 .830955$

Rasmussen LV, Rasmussen K, Reenberg A, Proud S (2012) A system dynamics approach to land use changes in agro-pastoral systems on the desert margins of Sahel. Agric Syst 107:56-64. https://doi.org/10.1016/j. agsy.2011.12.002

Razavi T, Switzman H, Arain A, Coulibaly P (2016) Regional climate change trends and uncertainty analysis using extreme indices: a case study of Hamilton, Canada. Clim Risk Manag 13:43-63. https://doi. org/10.1016/j.crm.2016.06.002

Reckien D (2014) Weather extremes and street life in India-implications of fuzzy cognitive mapping as a new tool for semi-quantitative impact assessment and ranking of adaptation measures. Glob Environ Chang 26: 1-13. https://doi.org/10.1016/j.gloenvcha.2014.03.005

Romankiewicz C, Doevenspeck M (2015) Climate and mobility in the West African Sahel: conceptualising the local dimensions of the environment and migration Nexus. In: Greschke H, Tischler J (eds) Grounding global climate change. Springer, Dordrecht, pp 79-100

Roncoli C (2006) Ethnographic and participatory approaches to research on farmers' responses to climate predictions. Clim Res 33:81-99. https://doi.org/10.3354/cr033081

Roncoli C, Ingram K, Kirshen P (2002) Reading the rains: local knowledge and rainfall forecasting in Burkina Faso. Soc Nat Resour 15:409-427. https://doi.org/10.1080/08941920252866774

Simelton E, Quinn CH, Batisani N et al (2013) Is rainfall really changing? Farmers' perceptions, meteorological data, and policy implications. Clim Dev 5:123-138. https://doi.org/10.1080/17565529.2012.751893

Sivakumar M (1988) Predicting rainy season potential from the onset of rains in Southern Sahelian and Sudanian climatic zones of West Africa. Agric For Meteorol 42:295-305

Sivakumar M, Hatfield J (1990) Spatial variability of rainfall at an experimental station in Niger West Africa. Theor Appl Climatology 42:33-39

Soglo YY, Nonvide GMA (2019) Climate change perceptions and responsive strategies in Benin: the case of maize farmers. Clim Chang 155:246-256. https://doi.org/10.1007/s10584-019-02452-3 
Sutcliffe C, Dougill AJ, Quinn CH (2016) Evidence and perceptions of rainfall change in Malawi: do maize cultivar choices enhance climate change adaptation in sub-Saharan Africa? Reg Environ Chang 16:12151224. https://doi.org/10.1007/s10113-015-0842-x

Tambo JA, Abdoulaye T (2012) Climate change and agricultural technology adoption: the case of drought tolerant maize in rural Nigeria. Mitig Adapt Strat Gl 17:277-292. https://doi.org/10.1007/s10113-012-03510

Van der Land V, Romankiewicz C, van der Geest K (2018) Environmental change and migration: a review of West African case studies. In: McLeman R, Gemenne F (eds) Routledge handbook of environmental displacement and migration (Pp. 163-177). Routledge

Warner K, Afifi T (2014) Where the rain falls: evidence from 8 countries on how vulnerable households use migration to manage the risk of rainfall variability and food insecurity. Clim Dev 6:1-17. https://oi. org/10.1080/17565529.2013.835707

Zampaligré N, Dossa LH, Schlecht E (2014) Climate change and variability: perception and adaptation strategies of pastoralists and agro-pastoralists across different zones of Burkina Faso. Reg Environ Chang 14:769-783. https://doi.org/10.1007/s10113-013-0532-5

Zhang X, Yang F (2004) RClimDex (1.0) user manual. Ontario: Downsview

Publisher's note Springer Nature remains neutral with regard to jurisdictional claims in published maps and institutional affiliations. 